\title{
Constraints Faced by the Gram Panchayat Members in Performing their Roles in Agricultural Development and Solution Perceived by them to Overcome the Constraints in Uttar Pradesh
}

\author{
Ramvinay Pal ${ }^{1 *}$, H. C. Singh ${ }^{2}$, Arun Rajbhar ${ }^{1}$, Ramratan Singh ${ }^{3}$ and Jyoti Gupta ${ }^{4}$ \\ ${ }^{1}$ Department of Extension Education, ${ }^{3}$ Department of Agricultural Economics \& Statistics, \\ ${ }^{4}$ Department of Home Science, C.S. Azad University of Agriculture \& Technology, Kanpur- \\ 208002, Uttar Pradesh, India \\ ${ }^{2}$ Department of Extension Education, Faculty of Agricultural Engineering \& Technology, \\ Campus, Etawah, Uttar Pradesh \\ *Corresponding author
}

\section{A B S T R A C T}

Keywords

Constrains,

Suggestions, Gram

Panchayat Members

Article Info

Accepted:

20 September 2020

Available Online:

10 October 2020
The present study was conducted in Azamgarh and Meerut district of Uttar Pradesh. Two blocks were selected from each district, thus total total four blocks selected. Five gram panchayats were selected from each block. In this way total 20 villages selected randomly. For secting the gram panchayat members, a list of members from 20 selected gram panchayats were prepared with the help of gram panchayat secretary. All the members of selected 20 gram panchayats were included in the sample. Finally, total 200 gram panchayat members were selected for the present study from all 20 gram panchayats. The information was collected with the help of structured interview schedule by interviewing personally to the respondents. It was found that lack of training to gram panchayat members was found as the main constraints for agricultural development, therefore, frequent training should be organized to introduce gram panchayat members with their role and responsibilities.

\section{Introduction}

The Institution of Panchayats in India dates back to ancient history when it performed the role of a village government. During British regime, these Panchayats were relegated a sub-servient position as the foreign rulers set up local self governments on the pattern of their own country. Mahatma Gandhi, Father of the Nation, conceived village Panchayats as a potential instrument for the socio- economic and political transformation of the rural society and cultivation of democratic way of life at the grass-root level. Gram Panchayat is the last link in the three-tier system of Panchayat Raj. As coordinating agency, Gram Panchayat and its members undertake all the developmental activities. Gram Panchayat members play the role of advisor to the rural people. They provide information about various government schemes to the people in the village. Thus the 
Gram Panchayat and its members have definitely and undoubtedly a key role to play in Panchayat Raj System. Gram panchayat members play a prime role in bringing about the welfare of the rural people. The Panchayat is expected mainly to promote economic, political and social development in the villages. This can happen only when the members performed their role effectively and efficiently. Then and then only the static society can be changed by the village Panchayat. The present study was searching out the constraints faced by GPMs in agricultural development with the following objectives.

\section{Objective of the study}

To analyse the constraints faced by the Gram Panchayat Members in performing their roles and solution perceived by them to overcome the constraints.

\section{Materials and Methods}

Keeping in the mind of objectives of study and the parameters to be studied an interview schedule was prepare to collect primary data from the respondents through personal interview. Collected data were analyzed by frequency and percentage and a rank order developed for this.

\section{Results and Discussion}

\section{Constraints}

It is evident from data presented in table-1 that the most serious constraint faced by the gram panchayat members during agriculture development was "lack of training" (95.50 percent). The second most constraint perceived by gram panchayat members was " less honorarium to panchayat members" (95.0 percent) followed by "lack of awareness about government schemes" (94.50 percent), "lack of information technology" (94.00 percent), "lack of specially fund for gram panchayat to agriculture development" (93.50 percent), "low support prices of cereal crop" (93.00 percent), "authority do not give importance to your opinions" (92.50 percent), "agriculture departmental staff is not interested in implementing various schemes in villages" (91.50 percent), "lethargy among the farmers" (91.00 percent), "less interest of mukhiya for agriculture development" $(89.00$ percent), "lack of co-operative societies" (88.50 percent),

Table.1 Constraints faced by the GPMs in performing their roles $(\mathrm{N}=200)$

\begin{tabular}{|r|l|c|c|c|}
\hline S.N. & \multicolumn{1}{|c}{ Constraints } & frequency & Percentage & Rank \\
\hline $\mathbf{1}$ & Lack of training & 191 & 95.50 & I \\
\hline $\mathbf{2}$ & Lack of co-operation from villagers & 112 & 56.00 & XXV \\
\hline $\mathbf{3}$ & Non co-operative among the GPMs & 166 & 83.00 & XVI \\
\hline $\mathbf{4}$ & Authority do not give importance to your opinions & 185 & 92.50 & VII \\
\hline $\mathbf{5}$ & $\begin{array}{l}\text { Agriculture departmental staff is not interested in } \\
\text { implementing various schemes in villages }\end{array}$ & 183 & 91.50 & VIII \\
\hline $\mathbf{6}$ & $\begin{array}{l}\text { Booklet of agricultural developmental schemes does not } \\
\text { available at proper time }\end{array}$ & 166 & 83.00 & XVI \\
\hline $\mathbf{7}$ & Farmers not believed in new technology earlier & 167 & 83.50 & XV \\
\hline $\mathbf{8}$ & High brokerage in agriculture product marketing & 176 & 88.00 & XII \\
\hline $\mathbf{9}$ & Lack of information technology & 188 & 94.00 & IV \\
\hline $\mathbf{1 0 .}$ & Due to personal work less time for agriculture & 155 & 77.50 & $\mathbf{X X I}$ \\
\hline $\mathbf{1 1}$ & Lack of resource for agriculture development work & 163 & 81.50 & $\mathbf{X V I I I}$ \\
\hline
\end{tabular}




\begin{tabular}{|c|c|c|c|c|}
\hline 12. & Less interest of mukhiya for agriculture development work & 178 & 89.00 & $\mathbf{X}$ \\
\hline 13. & High cost of inputs & 140 & 70.00 & XXIV \\
\hline 14. & Scattered and small land holding of farmers & 158 & 79.00 & XIX \\
\hline 15. & Complex and lengthy process of loan sanction & 169 & 84.50 & XIV \\
\hline 16. & Lack of co-operative societies & 177 & 88.50 & $\mathbf{X I}$ \\
\hline 17. & Less honorarium to panchayat members & 190 & 95.00 & II \\
\hline 18. & Lethargy among the farmers & 182 & 91.00 & IX \\
\hline 19. & $\begin{array}{l}\text { Lack of specially fund to gram panchayat for agriculture } \\
\text { development }\end{array}$ & 187 & 93.50 & $\mathbf{V}$ \\
\hline 20. & Casteism among villagers & 156 & 78.00 & $\mathbf{X X}$ \\
\hline 21. & Lack of co-operation from village level worker & 165 & 82.50 & XVII \\
\hline 22. & Non observation of suggestion by official & 152 & 76.00 & XXII \\
\hline 23. & Lack of awareness of duty among panchayat members & 145 & 72.50 & XXIII \\
\hline 24. & Unavaibility of improved seed and others inputs & 171 & 85.50 & XIII \\
\hline 25. & Low support prices of cereal crop & 186 & 93.00 & VI \\
\hline 26. & Non involment of women members in panchayat meeting & 98 & 49.00 & XXVII \\
\hline 27. & Interferences by the husband of women members & 105 & 52.50 & XXVI \\
\hline 28. & Lack of awareness about government schemes & 189 & 94.50 & III \\
\hline 29. & $\begin{array}{l}\text { Lack of knowledge about farmers production } \\
\text { organization(FPO) }\end{array}$ & 165 & 82.50 & XVII \\
\hline
\end{tabular}

Table.2 Suggestive measures to overcome the constraints faced by GPMs (N=200)

\begin{tabular}{|c|c|c|c|c|}
\hline S.N. & Suggestive measures & Frequency & $\begin{array}{l}\text { Percentag } \\
\text { e }\end{array}$ & Rank \\
\hline 1. & $\begin{array}{l}\text { Frequent training should be given to GPMs at village level about } \\
\text { agriculture development for increase their knowledge and awareness }\end{array}$ & 185 & 92.50 & I \\
\hline 2. & Removal of secondary status of women is needed & 102 & 51.00 & XVI \\
\hline 3 & Increase and regular provision of honorarium of GPMs & 168 & 84.00 & XIII \\
\hline 4. & $\begin{array}{l}\text { Provision of regular and adequate fund to gram panchayat specially for } \\
\text { agriculture development }\end{array}$ & 184 & 92.00 & II \\
\hline 5. & More information should be given by officials & 180 & 90.00 & VI \\
\hline 6. & $\begin{array}{l}\text { Subsidy should be provided to small and marginal farmers to purchase } \\
\text { inputs }\end{array}$ & 178 & 89.00 & VII \\
\hline 7. & Procedure for sanctioning loan should be simple and quick & 172 & 86.00 & $\mathrm{X}$ \\
\hline 8. & Cooperative societies should be formed in agriculture sector & 175 & 87.50 & VIII \\
\hline 9. & There should not be political interference & 183 & 91.50 & III \\
\hline 10. & $\begin{array}{l}\text { Extension worker should be faithfully to his work and should be timely } \\
\text { guidance to GPMs }\end{array}$ & 181 & 90.50 & $\mathrm{~V}$ \\
\hline 11. & $\begin{array}{l}\text { Good and well maintaining panchayat building should be available for } \\
\text { meeting and training of GPMs }\end{array}$ & 165 & 82.50 & XIV \\
\hline 12. & $\begin{array}{l}\text { Extension worker should convince farmers about the utility of new } \\
\text { technology and encourage them to take risk in adoption }\end{array}$ & 169 & 84.5 & XII \\
\hline 13. & Transparency should be government schemes & 174 & 87.00 & IX \\
\hline 14. & Farmer production organization(FPO) should be developed & 170 & 85.00 & $\mathrm{XI}$ \\
\hline 15 & Mukhiya should be interested in agricultural development & 182 & 91.00 & IV \\
\hline
\end{tabular}


"High brokerage in agriculture product marketing" (88.00 percent), "Unavaibility of improved seed and others input" (85.50 percent), Complex and lengthy process of loan sanction" ( 84.50 percent), "Farmers not believed in new technology earlier" (83.50 percent), "Booklet of agricultural developmental schemes does not available at proper time" as well as "Non co-operative among the GPMs" (83.00 percent) "Lack of co-operation from village level worker" as well as "Lack of knowledge about farmers production organization(FPO)" (82.50 percent), "Lack of resource for agriculture development work" (81.50 percent), "Scattered and small land holding of farmers " $(79.50 \%)$, "Casteism among villagers" (78.00\%), "Due to personal work less time for agriculture" (77.50\%), "Non observation of suggestion by official" (76.00\%), "Lack of awareness of duty among panchayat members" (72.50\%), "High cost of input" $(70.00 \%)$, "Lack of co-operation from villagers" $(56.00 \%)$, "Interferences by the husband of women members" $(52.50 \%)$ and "Non involment of women members in panchayat meeting" $(49.00 \%)$ were found to be less serious constraint perceived by the gram panchayat members during agriculture development.

In conclusion this is evident from table- 2 that the suggestive measures as stated by GPMs to overcoming the constraints in agriculture development programme can be placed in a descending order with their score and rank order viz., Frequent training should be organized to introduce GPMs with their role and responsibilities ranked $\mathrm{I}^{\text {st }} \quad(92.5 \%)$ followed by Provision of regular and adequate fund to gram panchayat specially for agriculture development ranked $\mathrm{II}^{\text {nd }}(92 \%)$, There should not be political interference (91.5\%) ranked III, Mukhiya should be interested in agricultural development (91\%) ranked IV, Extension worker should be faithfully to his work and should be timely guidance to GPMs (90.5\%) ranked V, More information should be given by officials (90\%) ranked VI, Subsidy should be provided to small and marginal farmers to purchase inputs (89\%) ranked VII, Cooperative societies should be formed in agriculture sector $(87.5 \%)$ ranked VIII, Transparency should be government schemes $(87 \%)$ ranked IX, Procedure for sanctioning loan should be simple and quick (86\%) ranked X, Farmer production organization(FPO) should be developed $(85 \%)$ ranked XI, Extension worker should convince farmers about the utility of new technology and encourage them to take risk in adoption (84.5\%) ranked XII, Increase and regular provision of honorarium of GPMs (84\%) ranked XIII, Good and well maintaining panchayat building should be available for meeting and training of GPMs $(82.5 \%)$ ranked IV, and Removal of secondary status of women is needed (51\%) ranked as XVI, respectively.

\section{References}

Bhosale, S.G. (2007). A study of role perception and role performance of women members in Gram Panchayat from Rahuri Taluka of Ahmednagar District. M.Sc. (Agri.) Thesis, Mahatma Phule Krishi Vidyapeeth, Rahuri.

Deshmukh J.M., Kshatriya A.M and Shinde A.V. (2013). Constraints faced by women member of Gram Panchayat. Agriculture Update, 8 (1):160-162.

Dedun V.S., Naik R.M. and Gamit P.S. (2016) Constraint feced by gram panchayat members in performing their role for village development. International Journal of Agriculture Sciences, 8 (21):1371-1372.

Garje, B.M. (1997). A study on role perception and role performance of the Gram Panchayat members from Haveli 
Taluka of Pune district. M.Sc. (Agri.) Thesis, Mahatma Phule Krishi Vidyapeeth, Rahuri

Khare A. L and Kadam R. P.(2018). Constraints Faced by the Village Leaders in their Role for Village Development in Maharashtra State. International Journal of Current Microbiology and Applied Sciences, 7:3988-3996

Pushpakumari, C.S. (2012). Extent of participation of women members in Mandal Panchayat activities - An exploratory study. M.Sc. (Agri.) Thesis, University of Agricultural Sciences, Bangalore.

Singh, R.K., Singh R.P., Singh A.K., Upadhyay S.P., Singh A.P. and Singh C.K. (2019). Role performance of gram panchayat members about agriculture development programmes in Faizabad district of Uttar Pradesh. Journal of Pharmacognosy and Phytochemistry, 8 (2):1885-1889.

\section{How to cite this article:}

Ramvinay Pal, H. C. Singh, Arun Rajbhar, Ramratan Singh and Jyoti Gupta. 2020. Constraints Faced by the Gram Panchayat Members in Performing their Roles in Agricultural Development and Solution Perceived by them to Overcome the Constraints in Uttar Pradesh. Int.J.Curr.Microbiol.App.Sci. 9(10): 2667-2671. doi: https://doi.org/10.20546/ijcmas.2020.910.321 